\title{
"The maize is the cost of the farming, and the cassava is our profit": smallholders' perceptions and attitudes to poor crop patches in the eastern region of Ghana
}

\author{
Ibrahim Wahab* (1), Ola Hall and Magnus Jirström
}

\begin{abstract}
Background: Crop yields are lowest in sub-Saharan Africa compared to other regions, and this is true even for such an important staple crop as maize. Persistence of patches of low crop vigour side-by-side to patches with healthier maize crops has been shown to significantly contribute to low yields on smallholdings. Farmers' perspectives on the presence of such poor patches are important as far as their on-farm investment attitudes are concerned. We analyse maize yield levels and farmers' perspectives of their production levels in two farming communities in rural Ghana.

Results: We find substantial potential for yield improvements; while local attainable yields (average of the yields attained by the top $10 \%$ of farmers in each village) were $4.4 \mathrm{t} / \mathrm{ha}$ and $3.6 \mathrm{t} / \mathrm{ha}$, average crop cut yields were $2.0 \mathrm{t} / \mathrm{ha}$ and $2.4 \mathrm{t} /$ ha for Asitey and Akatawia, respectively. As much as $62 \%$ of the maize fields in both study locations were unable to reach the respective average village yield level. From the photo-elicitation interviews, the general attitude of smallholders to the presence of poor patches is that of indifference. We find contradictions in farmers' perceptions and attitudes towards low yields. While more than half (54\%) perceived they were getting adequate yields relative to their expectations, an even greater proportion (88\%) of farmers interviewed aver that their plots could yield much more. Similarly, a significant majority (63\%) did not attempt to remedy the poor patches even though the same proportion perceive that it is worth it to invest in yield-improving inputs.

Conclusions: Farmers in such contexts view investments in fertilizers on their farms as too risky. As alternatives, they would rather invest their already limited resources in non-farm ventures. Farmers opt for yield optimization rather than maximization and this has important implications for diversification off the farm. These findings have important implications for smallholder households' ability to meet their subsistence needs and for efforts to reduce yield gaps on small farms particularly in resource-poor contexts.
\end{abstract}

Keywords: Smallholders, Yield gaps, Risk attitudes, Drones, Rural Ghana

\section{Introduction}

A major challenge confronting sub-Saharan Africa (SSA) is what has been termed the food security conundrum [1]. This conundrum relates to the twin challenge of

*Correspondence: ibrahim.wahab@keg.lu.se

Department of Human Geography, Lund University, Solvegatan 10, 223 62 Lund, Sweden providing adequate, affordable, and nutritious food for a continuously growing population while creating a stimulating environment conducive for increased agricultural production in a socially and environmentally sustainable manner [2]. This has become more critical against the backdrop of fast-growing population, low crop yields and large yield gaps, continuously fragmented farmlands due to population pressure in rural areas vis-à-vis appropriate credit to the original author(s) and the source, provide a link to the Creative Commons licence, and indicate if changes were made. The images or other third party material in this article are included in the article's Creative Commons licence, unless indicated otherwise in a credit line to the material. If material is not included in the article's Creative Commons licence and your intended use is not permitted by statutory regulation or exceeds the permitted use, you will need to obtain permission directly from the copyright holder. To view a copy of this licence, visit http://creativecommons.org/licenses/by/4.0/. The Creative Commons Public Domain Dedication waiver (http://creativecommons.org/publicdomain/zero/1.0/) applies to the data made available in this article, unless otherwise stated in a credit line to the data. 
the dominant land tenure systems, and the generally low prices farmers receive for their produce in SSA. The net effect of these is the dominance of farms which are too small to meet food and income needs which leads to households investing more in off-farm activities, with little incentive to intensify and improve production on the farm $[3,4]$. There is, however, a critical need to substantially ramp up production, with some estimates suggesting the need to double current levels $[5,6]$. This is most critical in SSA as per capita food production still lingers around 1960s levels when other places in Latin America and Asia have seen substantial growth in this metric [2]. Thus, while some agricultural regions in the Global North are producing close to the maximum attainable, most regions in SSA still contend with large yield gaps [6, 7]. The existence of such large yield gaps also means these areas have the highest potential to contribute to needed future production increases [8]. For environmental sustainability reasons, such production increases must come through already-cropped fields rather than expanding into currently uncultivated areas.

Sustainable intensification $[9,10]$ is therefore an important aim for regions in the Global South which have a large exploitable gap-difference between current yields and what is theoretically achievable [11]. There is consensus that the necessary technology and knowledge exist to achieve the needed production increases without bringing too much of currently uncultivated fields under cultivation [5]. This aim is also in line with Goal 1 (no poverty), Goal 2 (zero hunger) as well as Goal 8 (decent work and economic growth, and Goal 12 (responsible consumption and production) of the Sustainable Development Goals (SDGs) [12, 13]. The practical means to achieve these, however, are not straightforward.

Given that (i) more than $52 \%$ of the world remaining arable land is found in Africa [14]; (ii) much of the growth in demand is expected to emanate from SSA on the face of current population growth trajectories [15]; and yet (iii) the continent reports some of the largest crop yield gaps [16] and (iv) farmers are not always minded to maximize yields [17], there is critical need to understand the production challenges from farmers' perspective. Fundamentally, low yields occur because of constraints which discourage local food producers from increasing productivity [2].

Spatial variation in crop yields contributes to the general low levels of productivity. These variations range from the across ecological zones [18], within villages and adjacent fields $[19,20]$ and even within the same plots [21]. The presence and preponderance of poor patches side-by-side with good patches within same fields has been shown to be a major contributor to low crop yields at the plot levels [22, 23]. Reduction of the number, frequency and severity of poor patches on smallholdings is, thus, central to improving general farm productivity [24]. The present paper therefore seeks to analyse the perspectives of resource-poor farmers on the observed poor patches ${ }^{1}$ within their plots. It answers the questions as to why poor patches exist and persist in such numbers and frequency and whether farmers are concerned about their presence? Do they even consider efforts to remove poor patches as cost-effective and profitable? Farmer attitudes and perceptions are fundamental to the extent that their decisions and management activities are based on what they think as much as on the resources they can command and thus have important implications for policy and future efforts to increase yields.

Evaluating crop production through the concept of yield gaps, which is the difference between theoretical yields-potential yields or water-limited yield levels-and farmers' actual yield levels [2,11], is critical in the pursuit of sustainable intensification [9]. In close to 90\% of African countries, increases in cereal production in the last half century have been linked to increases in area harvested [25]. This means that the modest gains in crop production in this region is largely attributable to increases in area harvested-extensification, rather than increases in yield from the already cropped area-intensification [6]. This is, however, unsustainable given limitations on arable land. A more viable route is increasing crop yields by way of increased replacement of lost soil nutrients through increased fertilizer application, as well as increasing the use of improved seeds, herbicides, and machinery. A substantial proportion of food crops produced in Ghana is by rural smallholders who constitute as much as $90 \%$ of the farming population [26, 27]. These food producers rely predominantly on rudimentary tools, low input levels, small farm sizes and limited control over pests and diseases while contending with a complex web of socio-economic limitations. Given these production constraints, not enough is known about the ability of such producers to intensify production as this ability is largely world-region-specific [28].

As rational economic agents, farmers' decisions, choices, and actions are largely based on a satisficing attitude to options available to them with regard to their farm activities. This is because, a wrong step could easily lead to an entire household losing its main food and income source for several months. Farmers are therefore best placed to provide valuable insights into the

\footnotetext{
${ }^{1}$ Portions within maize fields which should have been covered by plants but are bare. Poor patches could result from poor germination, destruction by farm animals, pests and diseases, or poor rains. In Fig. 1, the poor crop patches correspond to areas within the plot coloured in red while the good patches correspond to areas populated by healthier green plants.
} 


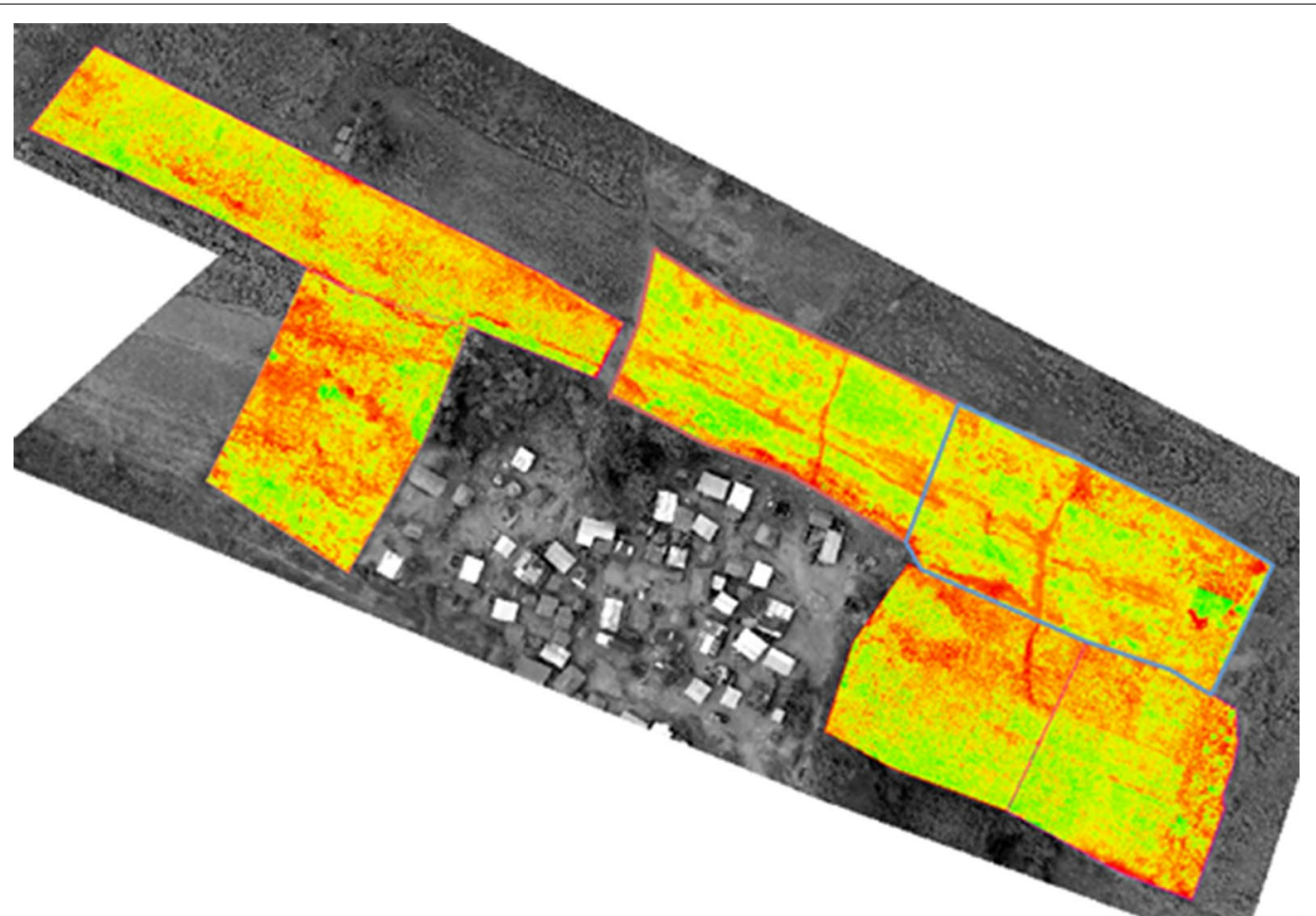

Fig. 1 A drone imagery showing within-field crop vigour variation in the eastern region of Ghana. Greener patches depict healthier maize plants while red patches indicate poor crop patches and/or bare soils

constraints that they often must deal with at the local level. For instance, a large proportion of smallholders are unable to benefit from the recent yield gains offered by crop genetic improvements due largely to continuous cropping without sufficient nutrient replacement $[8,29]$.

\section{Importance of farmers' perceptions}

Rather than view smallholders as mere labour contributors in the farming enterprise, premium ought to be put on the views of these primary agents of agriculture [30, 31]. Previously, studies on farmers' perceptions on challenges confronting agriculture were often downplayed with the view that perceptions were often transient and anecdotal. However, a number of studies have found this view untenable. Nigussie et al. [30] found, for example, that farmers' perceptions largely match empirical and theoretical findings on soil erosion determinants in Ethiopia. Similarly, Osgood et al. [32] found that farmers' perceptions and reports of climate risk events such as droughts are independently verifiable in multiple remotesensing datasets in Ethiopia. Kansiime et al. [33] analysed farmers' perceptions of the Fall Army Worm-FAW (Spodoptera frugiperda) infestation and its management in Zambia as a baseline for developing sustainable pest management strategies. An increasing body of literature in recent times is thus based on farmers' perceptions.
Generally, perceptions of farmers range from pessimism to satisfaction with farming [34]. Viewing farming with contentment rather than striving for better outcomes would have implications for farmers' attitudes to yield-improving innovations. There appears, however, to be a paucity of studies on the perceptions of farmers about their yield levels. This is surprising given the importance of increasing production and productivity to meet present and future food and feed need, particularly in the context of a continuously growing SSA population. This is also an important gap given the view that not only are farmers' knowledge and perceptions about crop yield-reducing factors and the perceived effectiveness of pest management strategies key to improving their productivity [33], but they also influence the broader on-farm investments and decisionmaking in agricultural management and production $[30,35]$ as well as off-farm economic activities. Of all the attitudinal variables, that towards risks is of major importance to farmers' decision-making processes [34]. This is because, at least for a certain category of households, the consequences of wrong decisions can be far-reaching. In a study on Ugandan farmers' risk attitudes and its effects on farmers' decisions, Haneishi, Maruyama [36] found that certain salient characteristics of farmers determine their risk attitudes and this, 
in turn, influence the risk levels they would be willing to assume.

\section{Pluriactivity as coping strategy}

The view of African smallholders as being strictly selfsufficient, subsistence-based producers has long been proven obsolete [37]. Rural households have a raft of income-generating activities that altogether constitute their livelihood portfolio [38]. Thus, while farming may remain the main occupation of most rural households wherever agro-climatic conditions allow, some level of diversification off the farm is common at all levels of welfare in much of SSA [39-41]. The extent to which smallholders access non-farm income sources seems less certain, however. In survey-based studies of smallholders in six SSA countries Jirström et al. [42] show that as much as $44 \%$ of the households lack any form of nonfarm incomes. However, households devote differing levels of attention and resources to own production of crops depending on their geography-the agricultural potential of their location and proximity to markets as well as the resources they can command $[39,43]$.

At the basic level of economic development, nonfarm activities tend to be closely related to agriculture so that growth in the agricultural sector leads to growth in the non-farm economy, by virtue of the forward and backward linkages between the sectors [39, 44-46]. As the economy expands, more profitable secondary sector activities become more attractive. The outcomes of households' engagements in these varying income-generating sources are influenced by factors including the gender of household heads and the region's agricultural potential in complex ways [38] and profitability of the offfarm activity [42]. Given that yield maximization is rarely the sole or even main objective of smallholders [40], the present study fills an important gap as farmers' choices and decisions have not garnered the deserved attention in studies on yield gaps.

\section{Data and methods}

\section{Description of study villages}

The present paper is based on data collected from two farming communities: Asitey in the Lower Manya Krobo municipality and Akatawia in the Upper Manya Krobo District, both of the eastern region of Ghana (Fig. 2). Of the two communities, the less rural Asitey (Lat. 6129601' Lon. $-0.013253^{\circ}$ ) is located less than a kilometre from Odumase, the Municipal capital while the more rural Akatawia (Lat. $6.283055^{\circ}$, Lon. $-0.128794^{\circ}$ ) is located some $9 \mathrm{~km}$ from Asesewa, its district capital.

In terms of climatic conditions, both communities fall within the Semi-Equatorial climate belt of West Africa and as such, experience two major seasons: the rainy (planting) season and the dry (Harmattan) season. Mean annual rainfall, distributed in a bimodal pattern, ranges between 900 and $1150 \mathrm{~mm}$ for Asitey and 900 and $1500 \mathrm{~mm}$ for Akatawia. The bimodality in the rainfall distribution allows for biannual maize crop cultivation with the major farming season starting in April and the minor season beginning in August.

Farming, which is a major economic activity in both Asitey and Akatawia, is largely rainfed and smallholderdominated with $66 \%$ and $73 \%$ of the population of the Lower and Upper Manya Krobo districts engaged in it [Ghana Statistical Service 47, 48]. While multi-cropping is common at both study locations, maize is the most important food crop and is often intercropped with cowpea and cassava; the latter is more common in Akatawia than Asitey. As a result, the processing of cassava into Gari is an important off-farm income-generating activity for women while for the men, off the farm engagements include carpentry and production of local gin, akpeteshie, in Akatawia. In Asitey however, the women largely engage in the sale of farm produce while the men are engaged as taxi drivers, lottery agents, and fishermen in the nearby Volta Lake. With regard to connectivity to markets, while Akatawia has a number of satellite markets within the district such as Asesewa and Sekesua, the road quality to the latter is dreadful for most parts of the year. Asitey, on the contrary, has smooth connectivity to the Agormanya Market which is the main commercial hub of the municipality as well as a direct linkage to the metropolitan markets of Accra and Tema.

\section{Yield gap measurement and challenges}

Yield gaps basically consider the difference between a benchmark yield-potential yield in irrigated systems or water-limited potential yields for rainfed systems-and what farmers can realize on their fields. However, measurement of these is not straightforward. For the benchmark water-limited potential yields, its calculation, is based on optimal or recommended planting dates, density, and cultivars. However, where farm inputs are costly or limiting, it is not possible to achieve optimal planting dates or use recommended cultivars [11]. Besides, the objective of farmers is often to maximize production from a cropping system rather than maximize yields from a particular crop, even if the crop is as important as maize is to the food security of the household [17]. Given the absence of any irrigation system for maize fields in the study areas, we operationalize theoretical yields as the locally attainable water-limited potential yields. This benchmark was computed as the average of the top $10 \%$ yielding fields in each village. The yield gap was, thus, the difference between this locally attainable water-limited potential yield and what farmers are able to achieve on 


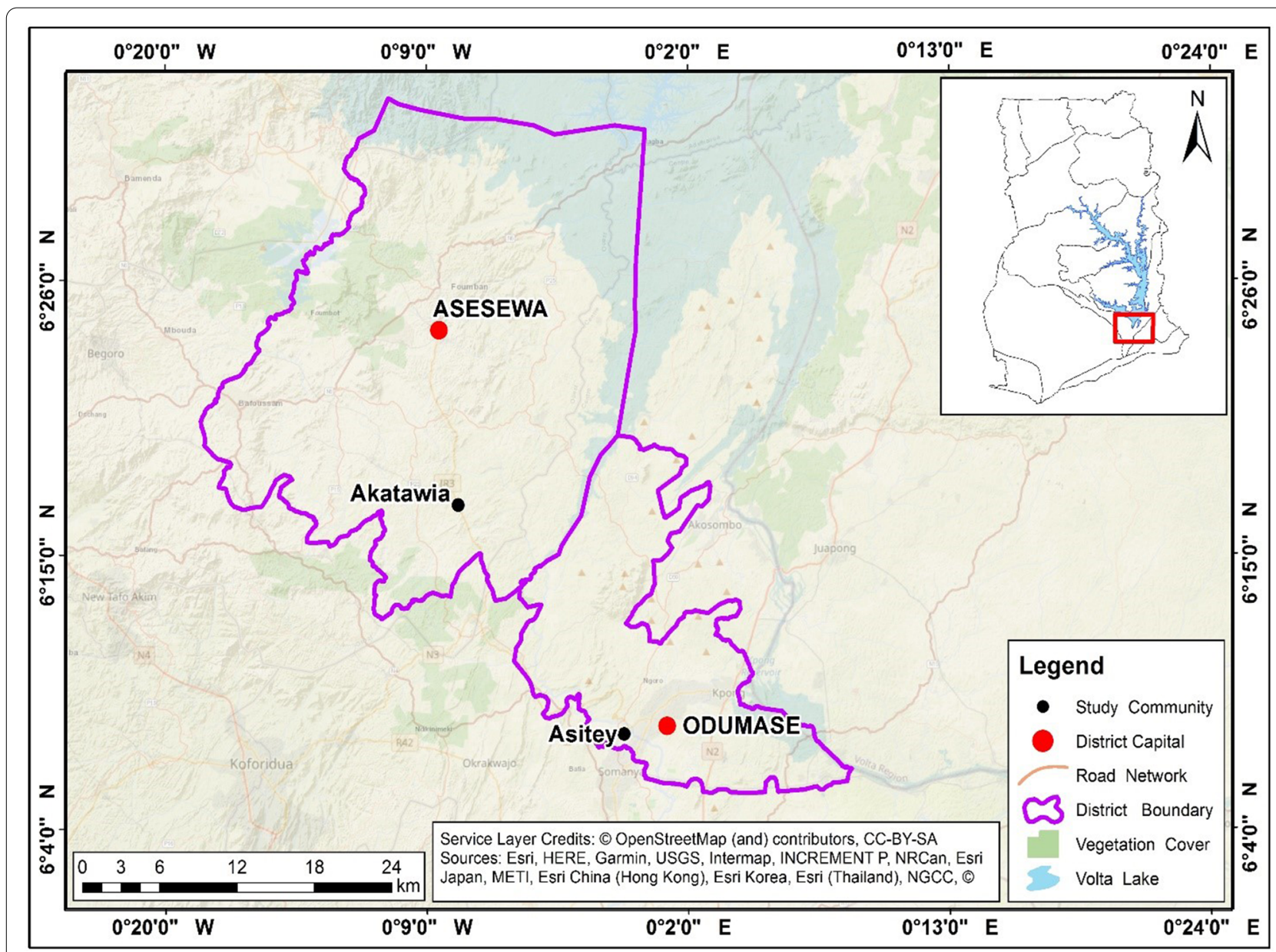

Fig. 2 Map of the study area showing the locations of Asitey and Akatawia and their district capitals

their fields [11]. We retrieved data on potential yields for the area from the Global Yield Gap Atlas (GYGA) database (https://www.yieldgap.org/). This was done using the Koforidua (Climate zone 9601) station as the reference point since both study communities are within a $25-\mathrm{km}$ radius.

\section{Study design}

While the study adopts a mixed methods approach, the focus is substantially on the qualitative data from photoelicitation interviews (PEIs) using drone photos of farmers' fields as visual guides and prompts. The quantitative leg of data collection was carried out in March-August 2016 during the major farming season while the PEIs were carried out in February 2019. A multi-level sampling strategy was implemented so that while the selection of the region, districts, and study communities was purposive, based on certain qualifying criteria, the sampling of farm households was through a simple random sampling approach. In the Ghanaian context, the choice of these districts and communities is based on their representativeness of the typical rural farming community on the agricultural dynamism and potential spectrum [49]. We used the original sample from the AFRINT project (https://www.keg.lu.se/en/research/research-proje cts/current-research-projects/afrint) since this was representative of the farming population of each village [50] as a starting sample. This was then supplemented with new farmers for households which were not available for the survey by reason of death or old-age of the respondent farmer and without a readily available next-of-kin to replace them. The final sample of 30 households for Akatawia was such that 23 were from farmers or nextof-kin of farmers involved in AFRINT III, with 7 being new, randomly sampled farmers while the 30 from Asitey comprised 20 from AFRINT and 10 new farmers.

\section{Plot selection and surveys}

Given the importance of maize, it was commonplace to find a household operating multiple maize plots, often at 
multiple locations. Such households were asked to indicate which one was the main plot to be surveyed. Others, however, had a single maize plot operated by the entire membership of the household. Also, there needed to be a sufficient level of homogeneity within sampled maize plots for the purposes of the present study. Thus, in a few instances, although the plot operator considered a plot as a single unit, its heterogeneity in terms of slope, plot history, or planting time was discernible, such a plot was further disaggregated into smaller, more homogeneous units. Thus, the 60 households yielded 87 comparable maize plots. In Akatawia, 20 of the households had only one maize plot, nine had two plots and one had three plots. All three plots were at distinct locations, with the man (household head), wife and eldest son in charge of one each. In Asitey, 18 of the sampled households had one maize plot, 11 had two plots and one had its field divided into three. In total, 26 of the plots were planted with intercrops which was predominantly cassava. These were analysed together with the mono-cropped fields as the intercrops were usually planted when maize plants had reached advanced stages. Maize yields were, thus, not expected to be significantly impacted by intercrops.

All 87 maize plots were surveyed over the course of the major farming season spanning March to August 2016. One of the plots in Asitey was dropped because it was missing important data points on crop harvest and flight. As a result, the final sample comprises 42 and 44 plots for Asitey and Akatawia, respectively. These were surveyed by transect walks, in-field measurements as well as aerial imaging using a quadcopter mounted with dual cameras; one of which had been modified to capture images in the near-infrared spectrum. The green normalized difference vegetation index-the ratio of the difference between the green and near-infrared bands-extracted from the drone imagery enabled the assessment of the density and intensity of vegetation cover [51]. This then became the crop health maps of each plot as sections of fields with more vigorous vegetation have greener colouration while bare lands and places where crops had withered had red and yellow colours, respectively (see Fig. 1). The analysed images were all recorded when crops were between 4 and 12 weeks old. A detailed description of the remotesensing system and the image processing protocols is available in Wahab et al. [52]. These crop health maps of individual plots were returned to the plot managers/owners for the photo-elicitation interviews (PEIs).

\section{Yield estimation approaches}

While each plot was treated as a unit, two distinct approaches were adopted to estimate crop yield levels; the first, based on farmers' own reports of their outputs, termed self-reported (SR) yields and the second, based on harvests from subplots using the crop cuts (CC) approach. The SR yields were derived from household surveys conducted soon after harvest during which farmers were asked to report overall crop output from each plot. This included maize harvested while green as well as that which was used as payment in-kind for labour or rental for land. Detailed probing was done to ascertain accurate outputs, especially in situations where farmers used non-standardized measurement units such as sacks and bowls. The CC yields were based on one $4 \mathrm{~m}$-by- $4 \mathrm{~m}$ subplot located in the approximate centre of each maize plot. These subplots were demarcated prior to planting to avoid biases in their placement. Care was taken to ensure that these $16-\mathrm{m}^{2}$ subplots, by and large, were representative of the larger maize plot and farmers were asked not to treat the subplots differently from the larger plot. The crops were allowed to dry in the field before harvesting, threshing, and weighing of the grains by field enumerators using digital scales. The moisture content for each crop cut was noted at $13 \%$ for subsequent standardization. The SR and CC yields were then estimated as follows:

$$
\begin{aligned}
& \text { Yield }_{\mathrm{SR}}=\frac{\text { Crop output }_{\mathrm{SR}}}{\text { Area }_{\mathrm{GPS}}} \text {, and } \\
& \text { Yield }_{\mathrm{CC}}=\frac{\text { Weighed output }_{\mathrm{CC}}}{16 \mathrm{~m}^{2}},
\end{aligned}
$$

where Yield $_{\mathrm{SR}}=$ farmers' self-reported maize yields; Crop output $\mathrm{SR}_{\mathrm{SR}}=$ total maize output in $\mathrm{kg}$ and converted to tonnes; $A_{\text {rea }}{ }_{G P S}=$ field area measured by walking the perimeter of each plot using a Garmin 64S GPS device; and Yield ${ }_{C C}=$ maize yields computed based on crop cuts; and weighed output ${ }_{C C}=$ weight of grains in $\mathrm{kg}$ harvested from each $16-\mathrm{m}^{2}$ subplot.

\section{Aerial photo-elicitation interviews}

Even before the PEIs, we organized a feedback workshop with farmers in each study village at which the findings from the quantitative survey were discussed at length. Agronomists from the larger research project were brought to interact with farmers and make recommendations on farm management activities. The importance of the timing of such critical activities as weed control and fertilizer application was discussed during these workshops. Farmers were also advised on more appropriate methods of fertilizer application. Farmers were then informed of our intention to interview them using the drone photos captured to further understand the persistence of poor crop patches on their plots. A total of 24 farming households were selected for the 
photo-elicitation interviews-12 from each community. In each village, the 12 interviewed households comprised 4 owners of averagely performing plots, 4 owners of highperformance plots, and 4 owners of plots which performed poorly. For our purposes, poor-performing plots yielded less than 2 tons/ha, averagely performing plots yielded between 2 and 3 tons/ha, and high-performing plots yielded above 3 tons/ha. Though largely arbitrary, this categorization fitted our yield dataset and was appropriate given that average yields, according to the Ghana Statistical Service, was 2.2 tons/ha and 1.9 tons/ha for Lower Manya Krobo and Upper Manya Krobo districts, respectively, in 2016 [53]. The synoptic view aerial photographs give allowed farmers a rare perspective of their plots which elicited some insightful conversations about their yield levels. The photo-elicitation interviews (PEIs) were qualitative in nature and were conducted using a semi-structured interview guide to elicit farmers' views on the poor patches that could be discerned from the aerial photographs of individual plots.

It is pertinent to acknowledge the possible pitfalls of relying on farmers perceptions given that the latter is not always factual. Like any other interviewees, farmers have the tendency to respond to interview questions in ways that are biased or has the potential to inure to furthering their perceived interests. Reliance on farmers' perceptions alone can be problematic. For example, farmers could answer questions regarding fertilizer use in ways that would position them to receive help from benefactors. In this study, we were conscious of this and took steps to validate their responses based on the aerial photos of their fields which are more objective. On such occasion, they often conceded shortcomings on their part.

\section{Results and discussion}

\section{Socio-demographic description of households}

As Table 1 shows, both study sites are largely similar in terms of average age and gender composition of households with the predominance of male-headship of households. At both Asitey and Akatawia, female-headed households constituted only a fifth of the overall sample. This may be attributed to the deeply patriarchal structure of society so that as long as the man is alive, he remains the de facto head of the household. Most of the about $20 \%$ females are, thus, widows heading single-parent households. With an average age of 56 and 54 years, the household heads are largely ageing in both Asitey and Akatawia. Despite this similarity, the household heads differed, even if only slightly, in terms of levels of formal education with household heads in Asitey having
Table 1 Descriptive statistics of the study villages

\begin{tabular}{|c|c|c|}
\hline \multirow[t]{2}{*}{ Variables } & \multicolumn{2}{|c|}{ Study villages } \\
\hline & Asitey & Akatawia \\
\hline \multicolumn{3}{|l|}{ Household head characteristics } \\
\hline Average age (years) & $55.7(2.1)$ & $54.1(2.0)$ \\
\hline Gender $($ male $=1$, female $=0$ ) & $0.79(0.1)$ & $0.80(0.1)$ \\
\hline Educational attainment $^{\mathrm{a}}$ & $1.8(0.2)$ & $2.1(0.2)$ \\
\hline \multicolumn{3}{|l|}{ Household characteristics } \\
\hline Household size & $6.9(0.5)$ & $7.0(0.5)$ \\
\hline $\begin{array}{l}\text { Economically inactive membership }(<16 \text { years } \\
\text { old) }\end{array}$ & $2.6(0.3)$ & $2.3(0.3)$ \\
\hline Average landholding, hectares & $3.6(0.5)$ & $5.6(0.6)$ \\
\hline $\begin{array}{l}\text { Non-farm income as proportion of hh income } \\
(\%)\end{array}$ & $43.1(4.2)$ & $35.0(3.7)$ \\
\hline Average distance to nearest market $(\mathrm{km})$ & $3.5(1.6)$ & $9.2(3.1)$ \\
\hline \multicolumn{3}{|l|}{ Plot characteristics } \\
\hline Average maize plot size, hectares & $0.41(0.05)$ & $0.42(0.04)$ \\
\hline Average land under fallow, hectares & $1.7(0.4)$ & $2.9(0.4)$ \\
\hline Average fertilizer quantities used (kg/ha) & $15.5(24.0)$ & $27(29.5)$ \\
\hline Proportion using improved seeds (\%) & 9.52 & 6.67 \\
\hline Proportion using recycled seeds (\%) & 78.57 & 75.56 \\
\hline
\end{tabular}

Field survey, 2016. Values in parenthesis are standard errors of the mean

a $0=$ no formal education, $1=$ primary education, $2=$ Junior High education, $3=$ Senior High education, $4=$ Tertiary education

terminated formal education at 9 years-Junior High School level-compared to 12 years-Senior High School levels-for Akatawia. This was somewhat unexpected given that Akatawia is more rural in structure relative to Asitey.

With regard to household characteristics, both villages generally had young and large households, often including members of the extended family. Household size was about seven on the average in both villages with almost half aged 16 or younger in Asitey while this reduces to about a third in Akatawia. We also find a high degree of diversification in livelihoods with non-farm income contributing about a third of the total household income at Akatawia and close to half at Asitey. A household is specialized if it receives more than three-quarters of its income from a single source and diversified if no one source contributes that magnitude [39].

Overall, Akatawia is more land-abundant than Asitey. This is demonstrable not only by the average household landholding, but also the average distance to the farm and the size of land under fallow. This notwithstanding, the average size of maize plots is essentially the same for both villages. This could be attributed to multiple factors, including farmers' unwillingness to cultivate larger plots. This is consistent with the findings of Jayne et al. [54] and Barrett et al. [55] of a negative relationship between 


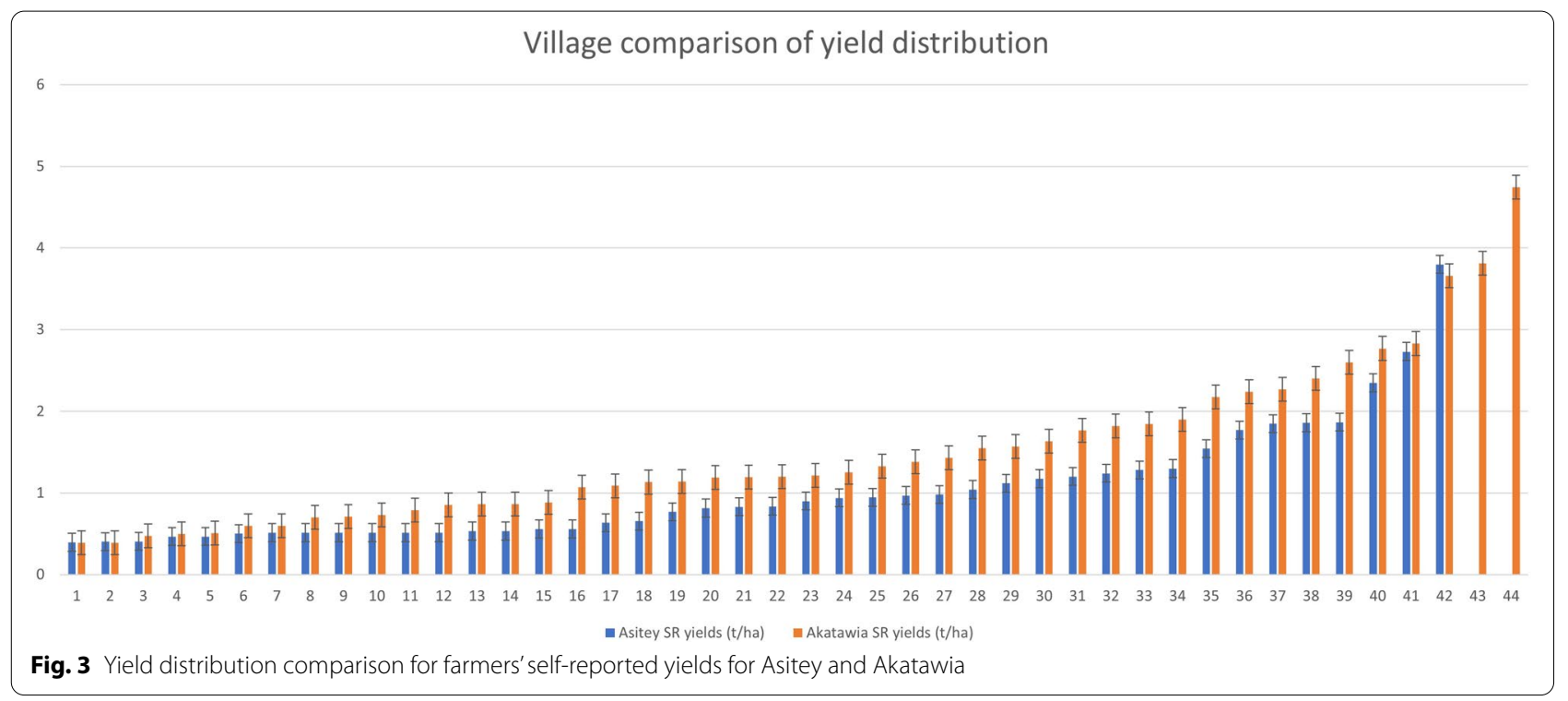

non-farm shares of total household income and farm sizes. The relatively small size of maize plots vis-à-vis average total landholding -9 and 14 acres for Asitey and Akatawia, respectively-would suggest intensification, rather than extensification, of farming activities. However, fertilization levels-a meagre $15 \mathrm{~kg} / \mathrm{ha}$ and $27 \mathrm{~kg} /$ ha for Asitey and Akatawia, respectively-are well below recommended rates of $110-130 \mathrm{~kg} / \mathrm{ha}$ in SSA [29]. The relatively lower levels of fertilizer use in Asitey relative to those in Akatawia can be attributed to differences in tenure systems, with farmers more willing to invest in fertilizers on plots over which they hold more secure tenure. The generally low use of fertilizer, coupled with limited use of improved seeds-only a tenth of the plots in Asitey and even a lower proportion in Akatawia were planted with improved seeds-with the vast majority relying on saved seeds. This is interesting as, overall, the general trajectory in the living income status in these villages has been improving in the last two decades. While the value of farm output per capita increased from USD 235 in 2008 to USD253 in 2013, real non-farm income earnings increased from USD 216 to USD 342 in the same period [56]. This suggests that while the living incomes of households in these villages are showing an upward trend, much of this increase is driven by the non-farm sector and the result of diversification.

\section{Village yield levels and large yield gaps}

Farmers' attention is gradually shifting away from the farm. This becomes apparent with the yield levels from the 2016 dataset. Using farmers' self-reported (SR) production data, average maize yields in both study communities were $1.3 \mathrm{t} / \mathrm{ha}$. Similar, for even the generally higher crop cuts $(\mathrm{CC})$ yields, the average is only slightly above $2 \mathrm{t} / \mathrm{ha}$. Remarkably, as much as $62 \%$ of the sampled fields did not reach the average SR and CC yields. Given that locally attainable yields - the average yield of the top performing $10 \%$ of farmers in each village-was considered a realistic benchmark for each study location [3, $11,57]$, there is substantial room for yield improvement even for this small sample of maize fields. Also given how prevalent poor patches are in almost all of the fields surveyed as shown in Fig. 2 and the impact the presence of such patches have on general crop yields as demonstrated by Masino et al. [23] and Marino and Alvino [22], understanding farmers' perspectives on their persistence becomes important.

Comparing these actual yield levels to water-limited yields data extracted from the GYGA, these villages show large yield gaps and substantial potential for yield improvements. In relative terms, our actual yield figures-1.3 t/ha for SR and 2.1 t/ha for CC-are comparable to Ya of $1.7 \mathrm{t} / \mathrm{ha}$ from GYGA for Koforidua under which these villages fall. Using the water-limited (Yw) yields from the database rather than the top $10 \%$ bestperforming farmers' field, our farmers have even larger yield gaps. Given $\mathrm{Yw}$ of $8.4 \mathrm{t} / \mathrm{ha}$ for that region, the exploitable Yg ranges from 7.4t/ha and $6.9 \mathrm{t} / \mathrm{ha}$ for $\mathrm{CC}$ yields and $6.4 \mathrm{t} / \mathrm{ha}$ and $6.1 \mathrm{t} / \mathrm{ha}$ for SR yields for Asitey and Akatawia, respectively. Figures 3 and 4 show the yield distribution comparison between the study villages for SR and CC yields. 


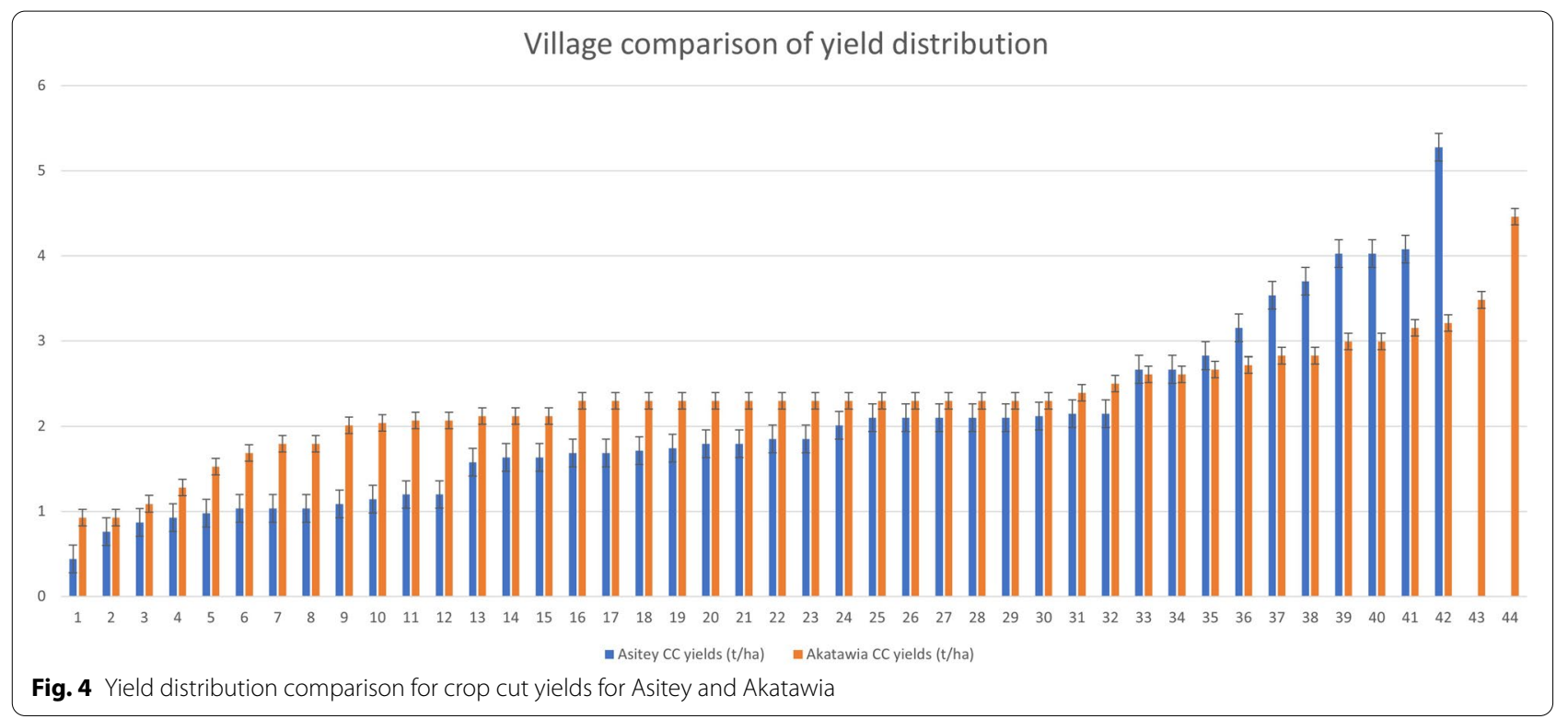

Table 2 Summary of farmers' $(N=24)$ perceptions of poor patches and yields

\begin{tabular}{llrr}
\hline & Summary of farmers' responses & Mean & SD \\
\hline Q1 & Sample questions & 2.46 & 0.78 \\
Q2 & Did you attempt to deal with the poor patches? & 1.83 & 0.96 \\
Q3 & Do you think you are getting adequate yields from your plot? & 1.21 & 0.59 \\
Q4 & Do you think the plot could yield more than it currently does? & 1.58 & 0.83 \\
\hline
\end{tabular}

Responses were either yes $=>1$, uncertain $=>2$, or no $=>3$

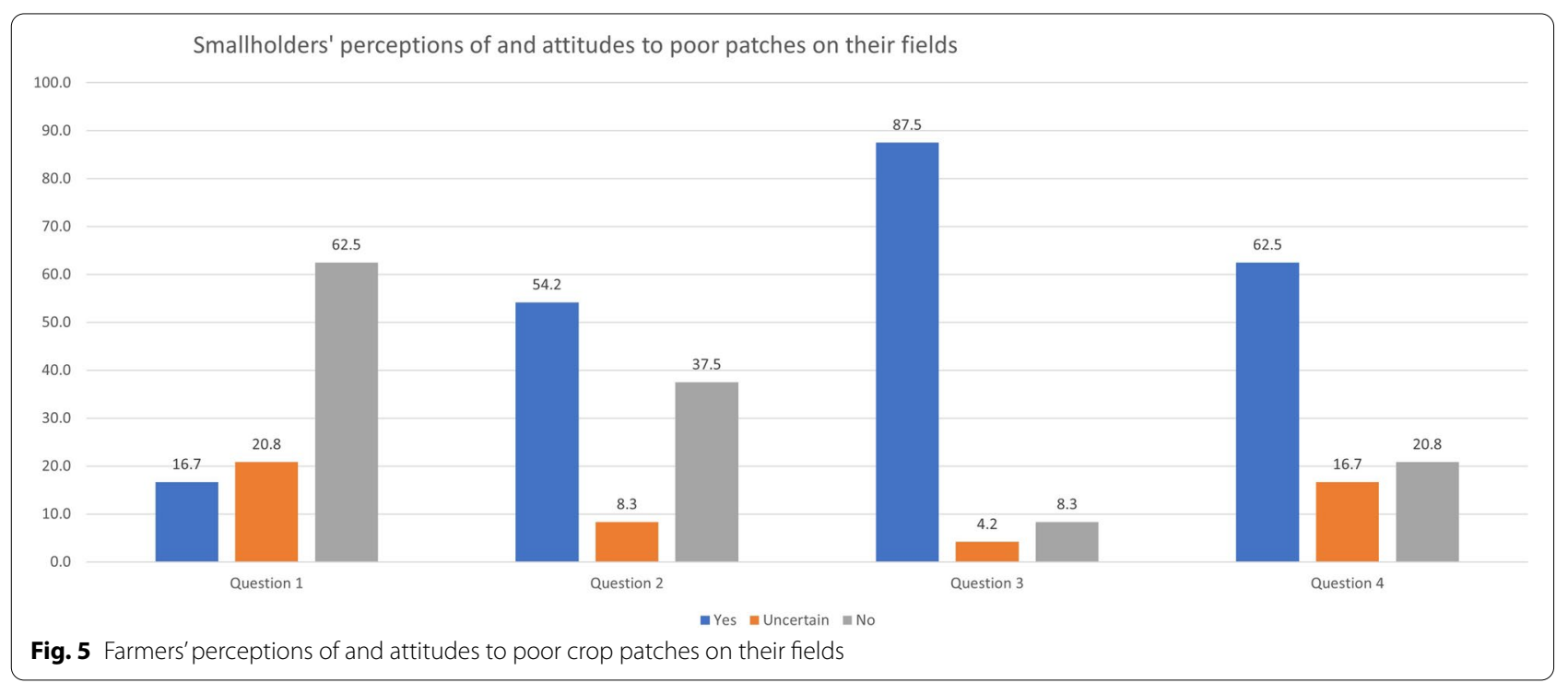




\section{Perceptions of indifference and satisfaction}

To elicit farmers' perceptions of and attitudes to the persistence of poor crop patches on their plots, four questions were posed directly to them. We further categorize questions 2 and 3 as gauging farmers' perceptions and 1 and 4 as measuring the attitudes (Table 2).

As Fig. 5 shows, farmers' perceptions seem somewhat contradictory. While more than half (54\%) answered in the affirmative to the question of if they were getting adequate yields ${ }^{2}$ from their plots (question 2), an even greater proportion (88\%) also perceived their plots could yield more than they are currently producing. The sense of contradiction can also be observed in their attitudes to lower yields. While a significant majority $(63 \%)$ say it is worth their efforts and resources to invest in yield-improving inputs (question 4), the same proportion of farmers did not attempt to deal with poor patches observable on their plots (question 1). Less than 1 in 5 farmers took any remedial action-re-planting maize or other crops, pruning surrounding trees, among otherson their plots. This suggests a perception of contentment and an attitude of indifference.

Reasons for perceiving their current productivity levels as sufficient are varied. A few of the farmers hold the view that given the present circumstances, fertilizer application does not make much of a difference (see Additional file 1: Appendix 1 for total $\mathrm{N}$ applied and SR and CC yields and yield gaps). This perception may be grounded on the fact that some of the farmers can access state lands which have not been under cultivation for several years at little or no financial cost in terms of rent. Having been left fallow for a decade or more, such parcels of lands are more fertile. Farmers in this category who cultivate such plots without fertilizer application do not observe much difference in yields compared to their counterparts who apply fertilizer on more intensively cropped plots. A farmer who belongs in the former category explains his rationale: "I am not sure [of being able to increase output with fertilizer application]. You see, people have been using fertilizers in our area [of farming] while I do not, but at harvest, whatever they get, I also get. Whether I can get more depends on the size of the plot. For the current plot size, I think I am getting the best [quantity] I possibly can" (55-year-old male farmer, Asitey). This farmer perceives that in the present circumstances, crop output could more realistically, be increased through extensification rather than intensification.

This has serious potential implications for the sustainability of agricultural production at broader scales. While sustainable intensification, which entails narrowing

\footnotetext{
${ }^{2}$ Adequate yields here are used in a generic sense to ask if farmers were content with the output levels from their maize fields.
}

current yield gaps on existing agricultural lands through improved efficiency in resource use $[5,10]$ seems to be the ideal means of meeting the growing food and feed need, these category of smallholders appear to prefer extensification. Given the finite nature of agricultural lands and the trajectory of population growth, increasing production through bringing more land under cultivation is not sustainable in the long run.

A second category of farmers rents plots at locations closer to their dwellings. Continuous cultivation, however, leads to not only nutrient mining but also heavy soil erosion on their plots. The combination of the two processes contributes to soils whose properties do not allow them to hold and use nutrients whenever the latter is supplied externally. For this category of farmers, shifting to new sites to allow current plots to adequately rejuvenate appears the soundest option though other factors militate against taking such steps. A farmer in this category notes: "I think I am getting sufficient yields. However, what we get is continuously reducing and this is why I will be using fertilizers in future. The other option would be to give up the plot to fallow for a couple of years, but the challenge is that I do not have other plots elsewhere" (65-year-old male farmer, Asitey). Other farmers from both study locations who cultivate own lands also expressed similar views. Apart from demonstrating their contentment even in the face of reducing outputs, the above excerpt also reveals that the category of farmers who cultivate on own, inherited or family farmlands are not inclined to rent additional farm plots.

The attitude of contentment seems to be underpinned by a philosophical and fatalistic view of life. This can be exemplified by the infusion of phrases in their responses such as 'if God permits', 'whatever God gives is acceptable', nothing can be humanly done about the poor patches', and 'hope for the best'. Their beliefs are based on their view that the amount and distribution of rainfall is the ultimate determinant of how crops perform. This is similar to the findings of Roobroeck, Palm [58] that across four study sites in DR Congo, Kenya, Nigeria and Tanzania, irregular rainfall patterns strongly limited soybean yield responses to fertilizer application, with maize non-response being greater on soils with high silt and/or cation imbalances. A metaanalysis by Ichami, Shepherd [59] similarly found that silt content, soil $\mathrm{pH}$, clay and rainfall were the main factors affecting nitrogen use efficiency. Farmers in our study argue that even when one invests in fertilizers, all investments would have gone to waste if the rains do not come at the right time because the crops would still not do well. As a 59-year-old male farmer at Akatawia succinctly puts it: "It is worthwhile to invest but remember that when it comes to farming, it all depends on the 
rains. Once the rains come at the appropriate time, we will get it [adequate outputs]. But we cannot control it [the rain], it is for God [to control], unlike the Asutuare people who can use irrigation". We could deduce that this farmer, like many others interviewed, would like to irrigate their crops. When asked, however, almost all of them held the view that it would be too expensive and not worth the effort and manpower to irrigate their maize crops. Were irrigation facilities available, most of interviewed farmers would rather use them on vegetables and cash crops such as tomatoes, peppers, cabbages, and okra than on maize crops.

It is pertinent to note, however, that their perceptions of contentment with current levels of production and apparent indifference to the prevalence of poor patches do not necessarily mean they under-utilize their plots. Indeed, some do not perceive their current yield levels as being worse than usual. As a farmer argues:

"If you are looking at only the maize, then you might say we did not get adequate yields from the plot. But if you are looking at the plot as a whole and the fact that we also got cassava and other crops from the same piece of land, then overall, I am happy with how much I am getting from the farming. We did not get adequate maize because we did not sow in rows and some portions were not good enough for maize but good for cassava and plantains. So, the way I see it, the maize is the cost of the farming, and the cassava is our profit" - A 74-year-old male farmer, Akatawia.

This excerpt demonstrates not only contentment with current levels of productivity but also limitations of current measures of farm productivity. As Wahab [21] concluded, farm productivity ought to be viewed in a holistic manner especially in such complex agriculture systems rather than on the basis of single crop output. Thus, perceptions of satisfaction despite current low levels are borne out of the aims and aspirations of individual farmers. Where the objective is to provide food for the household, the utilization of portions to produce other crops achieves the same objective of household sustenance. Neither of the current dominant yield measurement approaches-self reports of outputs through surveys and crop cuts-adequately take into consideration the importance farmers attach to intercrops and secondary crops [60].

\section{Yield stabilization versus maximization}

The study also finds that farmers primarily prioritize inter-seasonal yield stability rather than maximization. That is, rather than attempt to extract the maximum output possible from their respective plot, farmers generally aim for a consistent and stable level of output from one farming season to the next. They are fulfilled with this level of output if it meets their subsistence needs. As mentioned earlier and shown in Table 2, most of them (63\%) did not attempt to remedy poor patches through, for example, the application of fertilizer although the same proportion perceived it worthwhile to invest resources in such yield-enhancing inputs.

From the survey data, $62 \%$ of the overall sample applied at least some level of inorganic fertilizer. Disaggregated to the village level, however, only $43 \%$ of the farmers in Asitey applied inorganic fertilizers compared to $80 \%$ in Akatawia. These proportions are however likely to reduce significantly in present times given that the state-led fertilizer subsidy programme-Medium-Term Agricultural Sector Investment Plan I (METASIP I, 2011-2015) - in place at the time of the survey data collection has since been replaced with METASIP II (2014-2017). With this change, the effective cost of a bag of NPK fertilizer to the farmer increased from 30 Cedis in 2011 to 85 Cedis in 2016 [61] even though a stated aim of the change was to remove constraints and promote better access. This could have contributed to further cutbacks in fertilizer usage among farmers as a principal reason the interviewed farmers gave for not using adequate levels of inorganic fertilizers, if at all, was limited economic means at crucial times during the farming season. Several of the interviewed farmers responded like a 46-year-old female farmer in Akatawia who poignantly asserts: "As for fertilizer, everybody would have wished for it, [but] the main barrier is the money to purchase it; that is the main challenge. Sometimes, when one needs to purchase it, there is not enough money in the house".

The low levels of utilization of inorganic fertilizers are even more remarkable given that almost all the interviewed farmers agreed that their plots could yield much more than current levels and that the application of fertilizers could more than double their current outputs. They, however, perceive it to be imprudent to borrow money to purchase inputs when own resources are limited for two main reasons: first, the likelihood of falling into unsustainable debts if the rains fail and second, the unreasonable and expensive terms of local money lenders. As a farmer in one of the villages posits:

"It [the non-utilization of fertilizers] is due to financial problems. Someone might suggest we take a 
loan but that is risky because if the rains fail you, no matter the quantity of fertilizer one applies, the crops will still not do well, and the loan becomes your burden to find a different source to pay. This is the reason why we hesitate to take loans to support our farming activities" - 44-year-old male farmer, Asitey.

Another in Akatawia concurs by stating that:

"If one has the means then it makes sense to apply fertilizer but if not, it is not advisable to go and borrow because the terms can be bad. Some people go for loans for which you are required to use maize grains as payment. They will usually tell you if they gave you 50 Cedis for fertilizer, you pay with a bag of maize at the end of the season, and it will not matter to them if the selling price of the bag is 170 Cedis. They will still demand the one bag. Even if you go for a meagre 20 Cedis they will still charge you a bag of maize even if the bag of maize sells for 200 Cedis at the end of the season" - A 48-year-old female farmer, Akatawia.

These two excerpts demonstrate the level of risks that farmers assume when they decide to seek for loans to invest in their farming enterprises. The risk exposure sometimes can lead to the loss of more valuable properties such as livestock and even farmlands in situations where the amount involved is substantial. The excerpt from the female farmer in Akatawia above also brings to the fore the expensive terms of the loans; sometimes having to pay an interest anywhere between 300 and 1000\% on the loan amount. It is for these reasons that some of the farmers would make do with consistent, even if mediocre, levels of outputs rather than seek to maximize outputs with fertilizers they cannot afford, and which could be a waste if the rains delay. This also lends credence to the findings of Silva and Ramisch [40] that yield maximization is rarely the sole objective of farmers. Thus, though agriculture remains the main economic activity in much of rural SSA [39], farmers' objectives are not always to produce at the highest levels possible.

\section{Risk aversion leading to diversification from the farm}

We argue here that smallholders' preference for stabilized, rather than maximized yields is due to their risk aversion in the face of high levels of uncertainty. The uncertainty they contend with relates not only to the unpredictability of the rains [62], but also unpredictable and poorly functioning markets for farm inputs and outputs [50]. With regard to the unreliability of the rains, a 74-year-old male farmer in Asitey asserts: "there is always an element of chance with the rains. For example, it rained yesterday but nobody can say for sure that it will rain again today. So, once we have a heavy rain like yesterday, we go ahead to plant and then hope for the best". Another farmer stated that: "If I had put in extra fertilizer, herbicide and labour and the rains were as poor as they were, I would have run at a worse loss. The rains determine everything". Several farmers alluded to how the rainfall is central to everything else they do. These excerpts highlight the uncertainty that farmers operate under with regard to rainfall and how the latter influence their level of investment and attention they devote to their farm plots.

The risks farmers contend with has been exacerbated in the last few years in the wake of the invasion of the Fall Army Worm (FAW) on their farms. A young farmer at Asitey explains his motives for not cultivating his plot in the ensuing major season of 2019 as:

"Now, farming is all about how much money one can invest in it. From the clearing, through planting, weed control, to harvesting, all require heavy investment and if one cannot afford to risk one's capital, then one is better off not going into it because it is 50-50, win or lose. One could have the FAW destroy everything in one night" - A 39-year-old male farmer, Asitey.

Farmers are rational economic agents who are seeking to make the best of the circumstances in which they find themselves. Smallholders' livelihoods, and even sometimes, their very survival, demand that they make the best possible decision from a range of difficult options. Given that there are always household needs, smallholders tend to want to invest in ventures that promise the least level of risk. This is in line with Schultz [63] efficient, but poor hypothesis in which he contends that smallholders, by and large, are rational in their responses to high taxes, artificially low crop prices, and modest levels of agriculture extension services availed to them. Their satisficing behaviour is, thus, premised on the efficient allocation of the limited resources at their disposal [64-66]. The few who assumed the additional risk of investing in pesticides and insecticides to combat the FAW infestation on their plots, for example, realized their investments had been wasted as the chemicals were largely ineffective in controlling the infestation. The increased prevalence of the FAW infestation has also intensified farmers' dependence on pesticides with attendant environmental and public health implications [33]. Such farmers are now less motivated to undertake any additional investments in their farm plots. Against the backdrop of weak institutions, agriculture in the West African sub-region is, thus, characterized by inadequate use of external input, 
deficient land tenure systems, inadequate infrastructure to facilitate access to capital and markets with little use of external energy contributing to depleted soils [67]. Given these challenges, agriculture is often not an attractive economic venture. This agrees with Frelat et al. [68] position that improving market access and off-farm opportunities is a better approach to improving food security than focusing on agricultural production and increasing yields alone. Smallholders may also opt to not invest in improving agricultural productivity because the returns are not commensurate with other uses of capital and labour [2]. While several farmers were quick to retort that not much could be done when confronted with the deficits in their farm performance, their inherent agency implies that they employ a multiplicity of coping strategies to deal with these uncertainties.

On the farm, diversification of crops appears to be a major way to deal with the existence of these poor patches and yields. While the first instinct is to replant non-germinated parts of plots with the same maize, this often does not work since conditions in those sections have not changed. Farmers, therefore, now plant other crops such as cassava, groundnuts, and vegetables. This is done with the view that certain crops do much better under certain conditions which would not be conducive for other kinds of crops. This is alluded to by a 59 -yearold male farmer in Asitey when he states that: "Intercropping is very much a part of what we do here, especially of maize and cassava. The poor patches which cannot support maize would usually do well with cassava. Replanting with maize is sometimes not the best [course of action] because it may ultimately not do well". This ties in with the view of the farmer who postulates that maize covers the cost of farming and the intercrop serves as the profit of the farming enterprise. Other farmers who have the land resources or the means to rent new plots move maize cultivation to such new plots and allow the depleted plots to rejuvenate or cultivate them with beans and shallots. Although new plots are generally more fertile, they often come with the disadvantage of being further away and thus, take much longer time to reach.

Given these challenges, some farmers have chosen to de-emphasis farming as a means to attaining their livelihoods and rather invest in other, 'less risky', income-generating ventures. For males, such less-risky, more reliable income sources include fishing in the nearby Volta Lake, taxi driving, palm wine tapping and akpeteshie distillation. For the women, less-risky sources of income include bead making, trading in farm produce and cottage industries that process cassava into dough and gari. This is in line with Godfray et al. [2] who argue that in poorly functioning market conditions, the solution often lies completely outside of the food system. The ability to make this transition, however, depends on the level of resources-both financial and human-at their disposal $[38,42]$. Those who have been able to move to urban areas to seek formal employment in either the private or public sectors are those who have had an advanced level of education. Without the requisite level of education, such transitions often lead to even greater exposure to risks as there are often better social safety nets in rural settings than urban centres. Those with a sufficient level of resources and family engagements often venture into businesses which usually require huge capital outlay. A most attractive venture in this category in our study context is taxi operation. A farmer explains his motivations thus:

"I have a taxi I operate as well so I divide my time between the market days [2-3 days a week] when I operate the taxi and the remaining days on the farm. The thing with these two activities is that the taxi business brings in income every day but with the farm, one must wait till the end of the season before getting income from it. So, the taxi is very important for taking care of the family daily while at the end of the season, the income from the farm can go into something more substantial like school fees payment" - A 33-year-old male, Akatawia.

This relatively young farmer with a large household size-eight members-is only able to cater to the needs of the household by being pluriactive. Dependence on only farming as a source of livelihood would have led to untold hardships for the membership of his household. Other farmers who cannot command the huge initial capital outlay required to engage in the taxi business often engage in other ventures which have lower barriers of entry due to less capital requirement. Rural households, thus, have a raft of income-generating activities that constitute their livelihoods though farming remains important [38]. The ubiquity of diversification of livelihoods is in line with the findings of Davis et al. [39] who also find that while endowments and wealth play a role in driving engagement in different economic activities, some level of diversification is common at all levels of welfare. Despite its importance in household welfare, across large parts of SSA, participation in off-farm income-generating activities is not equally available to households with differing levels of resource endowment [69] and can often lead to social and economic stratification in rural areas [70].

These processes have occasioned some dynamics, hitherto not experienced and whose overall outcomes are difficult to predict with certainty. While smallholders seek to make decent livelihoods, whether on or off the farm, they prefer to maintain a certain level of agriculture 
portfolio. This is leading to use of labour-saving strategies in contrast to the land-saving strategies which characterized the early phases of the Green Revolution of Asia [71]. Farmers are therefore utilizing management practices that would demand less of their presence and labour on their farms. These include the increasingly heavier reliance on herbicides not just for weed control, but even for plot preparation for planting. These could potentially have grave implications for not only the sustainability of their farmlands, but also the food security situation of the household. The situation of farmer indifference exemplified in recognizing that fields could yield much more than current levels and yet unwilling or unable to take remedial steps to improve poor patches of crops is striking. Their continued dependence on the farm while lacking resources or incentive to invest to achieve sustainable intensification of production makes them reluctant farmers [1]. Against the backdrop of currents trajectories of population growth and crop production and productivity, challenges relating to malnutrition, starvation and food security, which are already in the wrong direction in SSA, are bound to worsen [72, 73]. This is particularly true for farming systems characterized by shrinking farm sizes and limited to a single cropping season a year [3]. Recent history has amply demonstrated that dependence on food imports is neither sustainable nor desirable [74]. Thus, market intensification - the need to provide enabling socio-economic environment-conceptualized as a third leg of sustainable intensification $[9,75]$ becomes a critical route improving yields, in addition to ecological and genetic intensification.

While we acknowledge that limitations of the present work with its case study design does not give adequate basis to generalize, evidence abounds across much of SSA of this conundrum that smallholders find themselves in. Our findings resonate with those by Ritzema et al. [4] who find that across 7 countries in East and West Africa, production intensification achieves little for most smallholders who are reluctant or unable to invest in their farms due to meagre returns in food and farm incomes. Thus, notwithstanding the potential for future intensification-more output with more inputs-this is presently not sustainable at the farm level in both Southern Ethiopia and Central Luzon, Philippines [5]. In the context of shrinking farm sizes and nutrient-mined soils, engagement in off-farm income-generating activity is a must rather than an option for continued sustenance [3]. The end goal for such farmers is the attainment of a certain minimal level of food production, even with preponderance of poor patches on plots, so that household resources and focus is directed off the farm.

\section{Conclusions}

The present paper analysed perceptions and attitudes of smallholders in resource-constrained rural communities to the presence of poor crop patches within their farm plots. The study finds farmers' overall perception of their current levels of production is contentment and indifference with a stoic outlook on their present predicament. Overall, more than half of the sampled farmers applied some level of fertilizers, though their levels of fertilization are far below recommended rates for yield gap closure. While almost all the farmers recognize that fertilizer usage could more than double their current output levels, the actual application is hindered, to a large extent, by limited financial means at crucial times of the farming season. Fertilizer use is also hampered by limited soil response in the context of increasing climate variability. Even though a few of the farmers avoid the utilization of herbicides and fertilizers for idiosyncratic reasons, a vast majority of them who do not use it cite inadequate financial means coupled with the uncertainty in the timing and intensity of the rains. Investments in fertilizers do not yield the desired returns in the absence of adequate and reliable rains. Contracting loans to purchase farm inputs does not appeal to farmers due to exorbitant and exploitative terms and the likelihood of debt accumulation resulting from uncertainty regarding rains. Farmers would, thus, rather invest their limited resources in other ventures such as trading, fishing, and other cottage industries such as beads making and cassava processing; activities they perceive as less risky. It is therefore important to understand the processes that are currently unfolding in this farming system and their long-term implications for rural households' ability to meet their food and feed needs.

These findings have important implications for the future of smallholder and family farms in rural Africa. While the farm as a source of income is crucial for the survival and wellbeing of farming households [76], those who can effectively combine farming with non-farm income-generating activities tend to do relatively better. Given the important roles that farm activities play in household subsistence and food security, how farmers perceive the challenges which confront them relative to their activities on their farms is critical. There is also the need to revisit the notion of performance in agriculture by integrating smallholders' perceptions because it is the latter that informs decision-making on the farm. This is critical for the debate on narrowing the yield gap of some of the most important crops. For most households who are self-sufficient in the staple crops such as maize, investments to further increase crop production tends to offer minimal returns. We therefore argue that yield 
gap analysis should be contextualized at the household and farm levels where farmers operate and should take into consideration the peculiar circumstances and risks farmers contend. While the reinstatement of support for farmers in the form of input subsidies would go a long way to alleviate the burden for farmers, what this study has also shown is the accentuated need to improve extension support services to farmers.

\section{Supplementary Information}

The online version contains supplementary material available at https://doi. org/10.1186/s40066-022-00361-w.

Additional file 1: Appendix 1. Plots for total nitrogen added through fertilizer application and various yield and yield gap measures. A shows total $\mathrm{N}$ applied against self-reported yields of farmers; B shows total $\mathrm{N}$ applied against yields measured by the crop cuts method of yield measurement: C shows total $\mathrm{N}$ applied against yield gap based on farmers' self-reported yields; and D shows total $\mathrm{N}$ applied against yields measured by the crop cuts method. Note: For estimating yield gaps ( $C$ and D), water-limited yields for the area from the GYGA database - $8.4 \mathrm{t} / \mathrm{ha}$ - is used as the attainable yield.

\section{Acknowledgements}

We acknowledge the help we received from local authorities and field assistants during data collection. We are especially grateful to the farmers in the two villages who magnanimously allowed us to use portions of their maize farms for our field surveys and experiments and dedicated their time for the in-depth interviews. The authors acknowledge the suggestions from reviewers which helped shape the final version.

\section{Authors' contributions}

IW, OH, and MJ conceived the paper, collected, curated the data, and wrote the methodology of the draft. IW analysed the data and wrote the draft of the manuscript. $\mathrm{OH}$ and $\mathrm{MJ}$ edited and the manuscript as well as funding acquisition, administration, and supervision. All authors revised and agreed to the manuscript in its present version. All authors read and approved the final manuscript.

\section{Authors' information}

IW is a postdoc researcher, $\mathrm{OH}$ is an Associate Professor, and $\mathrm{MJ}$ is a Professor: all at the Human Geography department of Lund University, 223 62, Lund, Sweden.

\section{Funding}

We received funding from The Swedish International Development Agency (SIDA), The Swedish Research Council (VR), and the Erasmus + International Credit Mobility Grant. Open access funding provided by Lund University.

\section{Availability of data and materials}

The dataset used and/or analysed to produce this manuscript are available from the corresponding author on reasonable request.

\section{Declarations}

\section{Ethical approval and consent to participate}

The data that this manuscript was derived from were collected under the aegis of the Afrint project which received ethical clearance from Lund University's Ethics Committee. Permission to proceed with the research was also obtained from the respective local authorities of the Lower and Upper Manya Krobo districts in Ghana. Respondents and informants were also informed of the purpose of the research and their rights to withdraw their consent of participation at any stage of the research. The collection and handling of the data has been in accordance with general data protection guidelines to ensure confidentiality and privacy.

\section{Consent for publication}

Not applicable.

\section{Competing interests}

We have no competing interests. The funders had no role in the design of the study, in the data collection and analysis, nor in the interpretation of the data. The funders did not have any role in the writing of this manuscript nor the publication of the same.

Received: 22 August 2021 Accepted: 12 January 2022

Published: 10 February 2022

\section{References}

1. Giller KE. The food security conundrum of sub-Saharan Africa. Glob Food Secur. 2020;26:100431.

2. Godfray HCJ, et al. Food security: the challenge of feeding 9 billion people. Science. 2010;327(5967):812-8.

3. Giller KE, et al. Small farms and development in sub-Saharan Africa: farming for food, for income or for lack of better options? Food Secur. 2021;13:1-24.

4. Ritzema RS, et al. Is production intensification likely to make farm households food-adequate? A simple food availability analysis across smallholder farming systems from East and West Africa. Food Security. 2017;9(1):115-31.

5. Silva JV, et al. How sustainable is sustainable intensification? Assessing yield gaps at field and farm level across the globe. Global Food Secur. 2021;30:100552.

6. Giller KE, et al. The future of farming: who will produce our food? Food Secur. 2021;13(5):1073-99.

7. Van Ittersum MK, et al. Can sub-Saharan Africa feed itself? Proc Natl Acad Sci USA. 2016;113(52):14964-9.

8. Tittonell P, Giller K. When yield gaps are poverty traps: the paradigm of ecological intensification in African smallholder agriculture. Field Crop Res. 2013;2013(143):76-90.

9. Godfray HCJ, Garnett T. Food security and sustainable intensification. Philosophical transactions of the Royal Society B: biological sciences. 2014;369(1639):20120273.

10. Cassman KG, Grassini P. A global perspective on sustainable intensification research. Nat Sustain. 2020;3(4):262-8.

11. van Ittersum MK, et al. Yield gap analysis with local to global relevancea review. Field Crop Res. 2013;2013(143):4-17.

12. UN. Transforming our world: The 2030 agenda for sustainable development. New York: United Nations Organization; 2015.

13. UN, The sustainable development goals report 2019, U. Nations, Editor. 2019, United Nations: New York.

14. Thomson, J.K., Rising Global Interest in Farmland: Can It Yield Sustainable and Equitable Benefits? By K. Deininger and D. Byerlee with J. Lindsay, A. Norton, H. Selod and M. Stickler. Washington DC: The World Bank (2011), pp. 214,£ 25.00. ISBN 978-0-8213-8591-3. Experimental Agriculture, 2011. 47(4): p. 730-730.

15. Canning D, Sangeeta R, Abdo SY. Africa's demographic transition: Dividend or disaster?, in Africa Development Forum Series. Washington: World Bank; 2015

16. Affholder $F$, et al. The yield gap of major food crops in family agriculture in the tropics: assessment and analysis through field surveys and modelling. Field Crop Res. 2013;2013(143):106-18.

17. Berre D, et al. Thinking beyond agronomic yield gap: smallholder farm efficiency under contrasted livelihood strategies in Malawi. Field Crop Res. 2017;214:113-22.

18. Falconnier $\mathrm{GN}$, et al. Unravelling the causes of variability in crop yields and treatment responses for better tailoring of options for sustainable intensification in southern Mali. Field Crop Res. 2016;187:113-26.

19. Gregory JP, George ST. Feeding nine billion: the challenge to sustainable crop production. J Exp Bot. 2011;62(15):5233-9.

20. Rurangwa E, Vanlauwe B, Giller KE. Benefits of inoculation, P fertilizer and manure on yields of common bean and soybean also increase yield of subsequent maize. Agr Ecosyst Environ. 2018;261:219-29. 
21. Wahab I. In-season plot area loss and implications for yield estimation in smallholder rainfed farming systems at the village level. GeoJournal. 2019;85(6):1553-72.

22. Marino S, Alvino A. Detection of spatial and temporal variability of wheat cultivars by high-resolution vegetation indices. Agronomy. 2019;9(5):226.

23. Masino A, et al. Spatial and temporal plant-to-plant variability effects on soybean yield. Eur J Agron. 2018;98:14-24.

24. Grisso R, et al. Interpreting yield maps: "I gotta yield map, now what?" Virginia Cooperative Extension Publications. 2009;442:442-509.

25. Onyutha $C$. African crop production trends are insufficient to guarantee food security in the sub-Saharan region by 2050 owing to persistent poverty. Food Security. 2018;10(5):1203-19.

26. GLSS-6. Ghana living standards survey round 6-Main report. Ghana Statistical Service: Accra; 2014.

27. SRID-MoFA, Agriculture in Ghana: Facts and figures, R. Statistics, and Information Directorate, Editor. 2013, Ministry of Food and Agriculture: Accra. p. 65

28. Neumann K, et al. The yield gap of global grain production: a spatial analysis. Agric Syst. 2010;2010(103):316-26.

29. Assefa BT, et al. Unravelling the variability and causes of smallholder maize yield gaps in Ethiopia. Food Secur. 2019;12(1):83-103.

30. Nigussie Z, et al. Farmers' perception about soil erosion in Ethiopia. Land Degrad Dev. 2017;28(2):401-11.

31. Snyder AK, et al. The yield gap: closing the gap by widening the approach. Exp Agric. 2016;53(3):445-59.

32. Osgood D, et al. Farmer perception, recollection, and remote sensing in weather index insurance: an Ethiopia case study. Remote Sensing. 2018;10(12):1887.

33. Kansiime KM, et al. Farmer perception of fall armyworm (Spodoptera frugiderda J.E. Smith) and farm-level management practices in Zambia. Pest Manage Sci. 2019;75(10):2840-50.

34. Kyeyamwa H, Verbeke W, Van Huylenbroeck G. Prospects for voluntary group marketing of livestock in rural Uganda: an empirical assessment of farmers' attitudes and intentions. Outlook Agric. 2008;37(3):177-84.

35. Moyo M, et al. Farmer perceptions on climate change and variability in semi-arid Zimbabwe in relation to climatology evidence. Afr Crop Sci J. 2012;20(2):317-37.

36. Haneishi $Y$, et al. Farmers' risk attitudes to influence the productivity and planting decision: a case of rice and maize cultivation in rural Uganda. Afr J Agric Resour Econ. 2014;9(4):309-22.

37. Bryceson DF. Deagrarianization and rural employment in sub-Saharan Africa: a sectoral perspective. World Dev. 1996;24(1):97-111.

38. Dzanku MF. Food security in rural sub-Saharan Africa: exploring the nexus between gender, geography and off-farm employment. World Dev. 2019;113:26-43.

39. Davis B, Di Giuseppe S, Zezza A. Are African households (not) leaving agriculture? Patterns of households' income sources in rural Sub-Saharan Africa. Food Policy. 2017;67:153-74.

40. Silva JV, Ramisch JJ. Whose gap counts? The role of yield gap analysis within a development-oriented agronomy. Exp Agric. 2018;55(2):311-38.

41. IFAD, Land tenure security and poverty reduction. 2015, International Fund for Agricultural Development. https://www.ifad.org/documents/ 38714170/39148759/Land+tenure+security+and+poverty+reduction. pdf/c9d0982d-40e4-4e1e-b490-17ea8fef0775: Rome.

42. Jirström M, Archila Bustos MF, Loison A. African smallholder farmers on the move: farm and non-farm trends for six Sub-Saharan African countries, 2002-2015. In: AnderssonDjurfeldt A, Dzanku FM, Isinika AC, editors. Agriculture, diversification, and gender in rural Africa: Iongitudinal perspectives from six African countries. Oxford: Oxford University Press, Oxford; 2018. p. 17-53.

43. Yaro JA. The perception of and adaptation to climate variability/change in Ghana by small-scale and commercial farmers. Region Environ Change. 2013;13(6):1259-72.

44. Lipton, M., The family farm in a globalizing world: The role of crop science in alleviating poverty, A. 2020 Vision for Food, and Environmental Initiative, Editor. 2005, International Food Policy Research Institute: Washington D.C.

45. Johnston FB, Mellor WJ. The role of agriculture in economic development. Am Econ Rev. 1961;51(4):566-93.

46. Haggblade S, Hazell BRP, Reardon TA, editors. Transforming the rural non-farm economy: opportunities and threats in the developing world.
Baltimore: John Hopkins University Press for International Food Policy Research Institute; 2007.

47. GSS, 2010 population and housing census: District analytical report. Upper Manya Krobo District, G.S. Service, Editor. 2014, Ghana Statistical Service: Accra.

48. GSS, 2010 population and housing census: District analytical report. Lower Manya Krobo Municipality, G.S. Service, Editor. 2014, Ghana Statistical Service: Accra.

49. Djurfeldt $G$, Aryeetey E, Isinika CA, African smallholders: Food crops, markets and policy, ed. Djurfeldt G, Aryeetey E, and Isinika CA. Oxfordshire: CAB International; 2011, 397.

50. Djurfeldt, G., et al., The Millennium Development Goals and the African Food Crisis - Report from the AFRINT II project, S. Swedish International Development Cooperation Agency Editor. 2011, Swedish International Development Cooperation Agency, Sida, Stockholm: Stockholm.

51. Rouse, J.W., et al. Monitoring vegetation systems in the Great Plains with ERTS. in Third ERTS Symposium. 1973. Goddard Space Flight Centre: The National Aeronautics and Space Administration

52. Wahab I, Hall O, Jirström M. Remote sensing of yields: application of UAV imagery-derived NDVI for estimating maize vigor and yields in complex farming systems in Sub-Saharan Africa. Drones. 2018;2(3):28.

53. MoFA-SRID, Agriculture in Ghana: Facts and figures 2016, R. Statistics, and Information Directorate of the Ministry of Food and Agriculture Editor. 2017, Statistics, Research, and Information Directorate of the Ministry of Food and Agriculture Accra.

54. Jayne ST, Mather D, Mghenyi E. Principal challenges confronting smallholder agriculture in Sub-Saharan Africa. World Dev. 2010;38(10):1384-98.

55. Barrett BC, Reardon T, Webb P. Nonfarm income diversification and household livelihood strategies in rural Africa: concepts, dynamics, and policy implications. Food Policy. 2001;26(4):315-31.

56. Dzanku FM, Sarpong DB. Spatial and gendered linkages between non-farm diversification and farm productivity in Ghana, in agriculture, diversification, and gender in rural Africa: Longitudinal Perspectives from Six Countries, A. Andersson Djurfeldt, F.M. Dzanku, and A.C. Isinika, Editors. 2018, Oxford University Press: Oxford. p. 196-215.

57. Silva JV, et al. Explaining rice yields and yield gaps in Central Luzon, Philippines: application of stochastic frontier analysis and crop modeling. Eur J Agron. 2017;2017(82):223-41.

58. Roobroeck D, et al. Assessing and understanding non-responsiveness of maize and soybean to fertilizer applications in African smallholder farms. Agric Ecosyst Environ. 2021;305:107165.

59. Ichami SM, et al. Fertilizer response and nitrogen use efficiency in African smallholder maize farms. Nutr Cycl Agroecosyst. 2019;113(1):1-19.

60. Sapkota BT, et al. Yield estimation of food and non-food crops in smallholder production systems. In: Rosenstock TS, et al., editors. Methods for measuring greenhouse gas balances and evaluating mitigation options in smallholder agriculture. Cham: Springer; 2016. p. 163-74.

61. Iddrisu AM et al. Implications of the Fertilizer-Subsidy Programme on Income Growth, Productivity, and Employment in Ghana. Partnership for Economic Policy Working Paper, 2020(2020-05).

62. Cobbinah PB, Anane GK. Climate change adaptation in rural Ghana: indigenous perceptions and strategies. Climate Dev. 2016;8(2):169-78.

63. SchultzTW. Transforming traditional agriculture. New Haven: Yale University Press; 1964

64. Ruthenberg H. Farming systems in the Tropics. Oxford: Clarendon Press; 1971.

65. Chayanov AV, A. V. Chayanov on the theory of peasant economy, Ed. D. Thorner, B. Kerblay, and R.E.F. Smith. 1966, Homewood, Illinois: Richard D. Irving, Inc.

66. Netting RM. Smallholders, householders: farm families and the ecology of intensive, sustainable agriculture. Stanford: Stanford University Press; 1993.

67. Callo-Concha D, et al. Farming in the West African Sudan Savanna: insights in the context of climate change. Afr J Agric Res. 2013;8(38):4693-705

68. Frelat $R$, et al. Drivers of household food availability in Sub-Saharan Africa based on big data from small farms. Proc Natl Acad Sci. 2016;113(2):458-63.

69. Haggblade $S$, Hazell P, Reardon T. The rural non-farm economy: prospects for growth and poverty reduction. World Dev. 2010;38(10):1429-41. 
70. Djurfeldt AA, Djurfeldt G. Structural transformation and African smallholders: drivers of mobility within and between the farm and non-farm sectors for eight countries. Oxf Dev Stud. 2013;41(3):281-306.

71. Houssou N, et al. Changes in Ghanaian farming systems: stagnation or a quiet transformation? Washington: International Food Policy Research Institute; 2016.

72. FAO, How to feed the world: The special challenge of Sub-Saharan Africa, F.a.A. Organization, Editor. 2009, Food and Agriculture Organization: Rome.

73. FAO. The state of food security and nutrition of the world 2018: building climate resilience for food security and nutrition. Rome: FAO; 2018.

74. De Graaff J, Kessler A, Nibbering JW. Agriculture and food security in selected countries in Sub-Saharan Africa: diversity in trends and opportunities. Food Secur. 2011;2011(3):195-213.

75. Conway G. One billion hungry, can we feed the world. New York: Cornell University Press; 2012

76. Carletto C, Jolliffe D, Banerjee R. From tragedy to renaissance: Improving agricultural data for better policies. J Dev Stud. 2015;51(2):133-48.

\section{Publisher's Note}

Springer Nature remains neutral with regard to jurisdictional claims in published maps and institutional affiliations.

- fast, convenient online submission

- thorough peer review by experienced researchers in your field

- rapid publication on acceptance

- support for research data, including large and complex data types

- gold Open Access which fosters wider collaboration and increased citations

- maximum visibility for your research: over $100 \mathrm{M}$ website views per year

At BMC, research is always in progress.

Learn more biomedcentral.com/submissions 